\title{
Malignancy and immune disorders in patients with hereditary angioedema
}

\author{
Peter Stepaniuk (D) and Amin Kanani
}

\begin{abstract}
Background: Hereditary angioedema (HAE) is an inherited condition manifesting as recurrent angioedema episodes which is caused by deficiency or dysfunction of $\mathrm{C} 1$ inhibitor. Although complement dysregulation has historically been shown to be associated with various malignancy and immune disorders, it is currently not known if HAE patients are at an increased risk of developing malignancy or autoimmune conditions.

Case presentation: We reviewed the charts of 49 HAE patients and identified 6 patients who had a co-existing malignancy diagnosis (two with breast cancer, one with melanoma, one with pancreatic cancer, one with renal cancer and one with cervical dysplasia) and 6 patients who had a diagnosis of a co-existing immune disorder (two with rheumatoid arthritis, two with ulcerative colitis, one with chronic urticaria with hypothyroidism and one with Sjogren's syndrome). Nearly all malignancy cases occurred in older HAE patients ( $>50$ years) and malignancy was diagnosed before HAE in 3 of the patients.

Conclusions: Our case series identified multiple hereditary angioedema (HAE) patients with co-existing malignancy and immune disorders. Based on these findings, we would advocate that physicians managing HAE patients should maintain a high index of suspicion for these conditions and that in patients with angioedema, C1 inhibitor deficiency and malignancy, a diagnosis of HAE should still be considered in addition to acquired angioedema (AAE).
\end{abstract}

Keywords: Hereditary angioedema, Malignancy, Cancer, Complement, Immune disorder, Autoimmune

\section{Background}

Hereditary angioedema (HAE) is a rare autosomal dominant genetic condition with inherited deficiency or dysfunction of $\mathrm{C} 1$ inhibitor due to a mutation in the SERPING1 gene. The overall prevalence of HAE is estimated to be about $1.1-1.6$ per 100,000 [1]. C1 inhibitor is a key regulator protein of the classical and lectin complement pathways as well as the intrinsic coagulation and kinin generation pathways. Its deficiency is associated with increased kallikrein activity and subsequent bradykinin production leading to angioedema. $\mathrm{C} 1$ inhibitor deficiency can also lead to activation of the classical complement pathway leading

*Correspondence: peter.stepaniuk@alumni.ubc.ca

Division of Allergy and Immunology, Department of Medicine, University

of British Columbia, 905-750 Broadway W, Vancouver, BC V5Z 1H8, Canada to decreased $\mathrm{C} 4$ which is not directly involved in the development of angioedema [1]. Acquired angioedema (AAE) is a separate clinical entity caused by consumption of $\mathrm{C} 1$ inhibitor which can lead to a similar phenotype as HAE. However, unlike HAE, AAE is not an inherited disorder. AAE is associated with malignancies, particularly B cell lymphoproliferative diseases, but may also be caused by autoantibodies directed against the $\mathrm{C} 1$ inhibitor molecule [2]. In addition to the pharmacologic treatment of angioedema episodes as in $\mathrm{HAE}$, treatment of the underlying malignancy or immune disorder associated with AAE can lead to decreased frequency of angioedema attacks [2]. In contrast to AAE, HAE is not known to be associated with either malignancy or immune disorders.

Malignancy is a prevalent condition with one study estimating 14.5 million Americans with a history of original author(s) and the source, provide a link to the Creative Commons licence, and indicate if changes were made. The images or other third party material in this article are included in the article's Creative Commons licence, unless indicated otherwise in a credit line to the material. If material is not included in the article's Creative Commons licence and your intended use is not permitted by statutory regulation or exceeds the permitted use, you will need to obtain permission directly from the copyright holder. To view a copy of this licence, visit http://creativecommons.org/licenses/by/4.0/. The Creative Commons Public Domain Dedication waiver (http:// creativecommons.org/publicdomain/zero/1.0/) applies to the data made available in this article, unless otherwise stated in a credit line to the data. 
cancer were alive in 2014 [3]. A recent study involving mouse models suggested that complement may play a role in the anti-tumor response and they observed that complement 3a receptor (C3aR) deficiency or inhibition was protective against melanoma, breast and colon cancers [4]. Upon review of the literature however, we could not identify any published studies that have evaluated whether malignancy is more prevalent in the HAE population. Early identification of malignancy in at risk populations is critical to improve survival in cancer patients [5]. Conversely, immune disorders are relatively rare conditions in the general population with prevalence rates of individual autoimmune diseases (e.g., rheumatoid arthritis, ulcerative colitis) reported to be less than $1 \%$ [6, 7]. Both deficiencies and activation of complement have been associated with autoimmune diseases, in particular systemic lupus erythematosus (SLE) and vasculitis [8]. It is proposed that complement deficiencies may predispose to autoimmunity due to defective clearance of immune complexes, impaired disposal of dying cells and development of abnormal peripheral tolerance [9]. A few studies have investigated whether there is an association between HAE and autoimmunity, however they have all had varying results [10-13]. However, a recent systemic review has identified 155 individual occurrences of HAE and autoimmune disease out of 2880 records, with SLE being the most common [14]. If malignancy and/or immune disorders are more prevalent in individuals with HAE, this could influence guidelines and screening of this patient population.

\section{Case presentation}

This case series was conducted in a mixed pediatric/ adult practice, private allergy clinic in Vancouver, British Columbia, Canada. Patient charts were reviewed if the patient had a confirmed diagnosis of HAE based on prior abnormally low $\mathrm{C} 1$ inhibitor functional testing on at least two separate occasions, and either confirmatory genetic testing showing a pathologic mutation in SERPING1 or a family history of HAE. This diagnostic criterion of HAE is based on the International/Canadian Hereditary Angioedema Guidelines [15]. Individuals with other forms of angioedema such as acquired angioedema, ACE-inhibitor associated angioedema or hereditary angioedema with normal $\mathrm{C} 1$ inhibitor were excluded. Malignancy and immune disorder diagnoses were based on either patient reported history of condition or based on details provided in other medical subspecialty consultation letters (e.g., rheumatology, oncology). Malignancy included any form of malignant cells in any body system (including dysplasia). Immune disorders were defined as conditions involving dysfunction of the immune system including autoimmune diseases and primary immunodeficiencies.

49 charts of patients with HAE were reviewed and we identified six patients with a documented diagnosis of malignancy and six patients with a documented diagnosis of an immune disorder. A variety of malignant conditions were identified including two patients with breast cancer, one with melanoma, one with pancreatic cancer, one with renal cancer, and one with cervical dysplasia. All those with a diagnosis of malignancy were age 50 or greater at the time of diagnosis, with the exception of one patient who was diagnosed with cervical dysplasia in her early $40 \mathrm{~s}$ (Table 1). All individuals with a malignancy diagnosis either had a convincing family history of HAE following an autosomal dominant inheritance or had genetic testing that confirmed a diagnosis of HAE (as opposed to a suspected diagnosis of malignancy associated AAE). Three of these patients were diagnosed with malignancy prior to being diagnosed with HAE.

Six patients reported a diagnosis of an immune disorder including two patients with ulcerative colitis, two patients with rheumatoid arthritis, one patient with Sjogren's syndrome, and one patient with hypothyroidism and chronic spontaneous urticaria (CSU). The youngest patient identified with an immune disorder was Patient 8 , who indicated that she was diagnosed with ulcerative colitis at age 19 (Table 2). The age of diagnosis of the immune disorder was not available for any of the other patients, however at the time of our data collection, three patients were aged 18-49 and three patients were aged 50 or older. Both patients with ulcerative colitis (Patient 8 and Patient 11), required management with biologic therapy. No patients were identified with a primary immunodeficiency.

\section{Discussion and conclusions}

Nearly all of the cases of malignancy we identified in our HAE population occurred in older adults ( $>50$ years) and we detected a variety of malignant conditions including breast cancer, melanoma, pancreatic cancer, renal cancer and cervical dysplasia. These observations raise the possibility of an increased incidence of malignant conditions in older HAE patients ( $>50$ years). There has not been any previous published data that has investigated if patients with $\mathrm{HAE}$ are at an increased risk of malignancy. In our study, three patients were formally diagnosed with $\mathrm{HAE}$ after their malignancy was diagnosed. As HAE and AAE can present very similarly, we would advocate that older patients with malignancy who develop C1 inhibitor deficiency and angioedema, a high index of suspicion of HAE should be maintained as this could potentially identify relatives with undiagnosed HAE. Further cross-sectional studies with a larger sample 
Table 1 Details of HAE patients with Malignancy Diagnosis

\begin{tabular}{|c|c|c|c|c|c|c|c|}
\hline Patient number & $\begin{array}{l}\text { Age at } \\
\text { time of } \\
\text { study }\end{array}$ & Sex & $\begin{array}{l}\text { Age of } \\
\text { HAE } \\
\text { diagnosis }\end{array}$ & Details of HAE diagnosis & Type of malignancy & $\begin{array}{l}\text { Age of } \\
\text { malignancy } \\
\text { diagnosis }\end{array}$ & $\begin{array}{l}\text { Extent of malignancy and } \\
\text { treatment }\end{array}$ \\
\hline Patient 1 & 57 & $\mathrm{~F}$ & 41 & $\begin{array}{l}\text { Multiple family members } \\
\text { with HAE on paternal side }\end{array}$ & Breast & 54 & $\begin{array}{l}\text { Invasive ductal } \\
\text { carcinoma - ER/PR +, HER2 } \\
\text { equivocal, treated with surgery } \\
\text { and post-menopausal state }\end{array}$ \\
\hline Patient 2 & 58 & M & 12 & 8 family members with $\mathrm{HAE}$ & Melanoma & 56 & $\begin{array}{l}\text { Stage } 3 \text { with unknown } \\
\text { primary, treated with surgery } \\
\text { and chemotherapy }\end{array}$ \\
\hline Patient 3 & 70 & $\mathrm{~F}$ & 66 & $\begin{array}{l}\text { Sister, father and daughter } \\
\text { with HAE }\end{array}$ & Pancreatic & 70 & $\begin{array}{l}\text { Metastatic, passed away } \\
\text { shortly after diagnosis }\end{array}$ \\
\hline Patient 4 & 46 & $\mathrm{~F}$ & 42 & $\begin{array}{l}\text { Mother and maternal aunt } \\
\text { with HAE }\end{array}$ & $\begin{array}{l}\text { Cervical dysplasia } \\
\text { (ASC-H, prior HSIL) }\end{array}$ & $\begin{array}{l}\text { Early } 40 \mathrm{~s}, \\
\text { prior to HAE } \\
\text { diagnosis }\end{array}$ & $\begin{array}{l}\text { Localized, treated with } \\
\text { Hysterectomy. Currently being } \\
\text { investigated for bladder cancer }\end{array}$ \\
\hline Patient 5 & 58 & $\mathrm{~F}$ & 56 & $\begin{array}{l}\text { Brother and nephew with } \\
\text { HAE }\end{array}$ & Breast & 50 & $\begin{array}{l}\text { Treated with mastectomy and } \\
\text { tamoxifen for five years }\end{array}$ \\
\hline Patient 6 & 74 & $\mathrm{~F}$ & 73 & $\begin{array}{l}\text { Mutation in SERPING1, } \\
\text { suspected family } \\
\text { history (currently being } \\
\text { investigated) }\end{array}$ & Renal & 62 & $\begin{array}{l}\text { Metastatic, treated with } \\
\text { nephrectomy, immunotherapy, } \\
\text { and localized radiation }\end{array}$ \\
\hline
\end{tabular}

ER estrogen receptor, $P R$ progesterone receptor, HER2 Herceptin receptor, ASC-H atypical squamous cells, HSIL high-grade squamous intraepithelial lesion

Table 2 Details of HAE patients with immune disorder diagnosis

\begin{tabular}{lllll}
\hline Patient number & $\begin{array}{l}\text { Age at time of } \\
\text { study }\end{array}$ & Sex & Immune disorder & Other details and treatment \\
\hline Patient 7 & 41 & F & Rheumatoid arthritis & Managed with hydroxychloroquine and methotrexate \\
Patient 8 & 31 & F & Ulcerative colitis & Managed with infliximab \\
Patient 9 & 90 & F & $\begin{array}{l}\text { Sjogren's syndrome } \\
\text { Hypothyroidism and CSU }\end{array}$ & \\
Patient 10 & 42 & F & Ulcerative colitis & Managed with ustekinumab \\
Patient 11 & 64 & M & Rheumatoid arthritis & $\begin{array}{l}\text { Also, history of renal transplant due to ESRD secondary to } \\
\text { type 2 DM, immunosuppressed with MMF, tacrolimus and } \\
\text { Patient 12 }\end{array}$ \\
& 67 & & & Prednisone \\
\hline
\end{tabular}

CSU chronic spontaneous urticaria, ESRD end-stage renal disease, DM diabetes mellitus, MMF mycophenolate mofetil

size would be needed to determine if there is truly an associated relationship.

We identified six HAE patients with a diagnosis of a co-existing immune disorder. Our data is consistent with other studies that have showed a higher incidence of autoimmune conditions in patients with HAE [8]. The exact pathophysiology to explain this association is yet to be elucidated, although many complement deficiencies are known to be associated with autoimmunity. Inherited $\mathrm{C} 1 \mathrm{q}, \mathrm{C} 1 \mathrm{r}, \mathrm{C} 1 \mathrm{~s}, \mathrm{C} 4$ and $\mathrm{C} 2$ deficiency have all been found to be associated with an increased incidence of SLE [8]. A small retrospective study observed that HAE patients receiving $\mathrm{C} 1$ inhibitor replacement therapy had subsequent fewer physician visits for autoimmune disorders than patients with HAE who were not treated with $\mathrm{C} 1$ inhibitor replacement and concluded that normalization of complement levels may have a positive impact on coexisting autoimmune diseases [16]. These findings have yet to be verified on further studies, but support the hypothesis of complement deficiencies contributing to autoimmunity.

Our case series has identified multiple hereditary angioedema (HAE) patients with co-existing malignancy and immune disorders. Although we are limited by our small sample size and lack of a control population, based on these findings we would recommend that physicians managing HAE patients should maintain a high index of suspicion of co-existing malignancy and immune disorders. We would also recommend that a diagnosis of HAE should still be considered in patients 
presenting with angioedema, $\mathrm{C} 1$ inhibitor deficiency and malignancy in addition to AAE.

\author{
Abbreviations \\ HAE: Hereditary angioedema; AAE: Acquired angioedema; CSU: Chronic \\ spontaneous urticaria.
}

\section{Acknowledgements}

Not applicable.

\section{Authors' contributions}

PS engaged in background research on the subject, collection of patient data, data analysis and was the major contributor in writing the manuscript. AK oversaw the study and reviewed the submitted manuscript. All authors read and approved the final manuscript.

\section{Funding}

No formal funding was obtained for this study.

\section{Availability of data and materials}

All data generated or analyzed during this study are included in this published article.

\section{Declarations}

Ethics approval and consent to participate

This study was approved by the ethics committee at the University of British Columbia. All participants read and signed a consent form agreeing to participate in this study.

\section{Consent for publication}

Not applicable.

\section{Competing interests}

AK received funding from CSL Behring, Takeda and BioCryst for research and advisory board. Funders played no role in any aspect of this study. The rest of the authors declare that they have no relevant conflicts of interest.

Received: 19 August 2021 Accepted: 1 November 2021

Published online: 19 December 2021

\section{References}

1. Aygören-Pürsün E, Magerl M, Maetzel A, Maurer M. Epidemiology of Bradykinin-mediated angioedema: a systematic investigation of epidemiological studies. Orphanet J Rare Dis. 2018;13(1):73.

2. Zingale LC, Castelli R, Zanichelli A, Cicardi M. Acquired deficiency of the inhibitor of the first complement component: presentation, diagnosis, course, and conventional management. Immunol Allergy Clin North Am. 2006;26(4):669-90.

3. DeSantis CE, Lin CC, Mariotto AB, Siegel RL, Stein KD, Kramer JL, et al. Cancer treatment and survivorship statistics, 2014. CA Cancer J Clin. 2014;64(4):252-71.

4. Nabizadeh JA, Manthey HD, Steyn FJ, Chen W, Widiapradja A, Md Akhir $\mathrm{FN}$, et al. The complement C3a receptor contributes to melanoma tumorigenesis by inhibiting neutrophil and CD4+ T cell responses. J Immunol. 2016;196(11):4783-92.

5. Winters S, Martin C, Murphy D, Shokar NK. Breast cancer epidemiology, prevention, and screening. Prog Mol Biol Transl Sci. 2017;151:1-32.

6. Cooper GS, Stroehla BC. The epidemiology of autoimmune diseases. Autoimmun Rev. 2003;2(3):119-25.

7. Molodecky NA, Soon IS, Rabi DM, Ghali WA, Ferris M, Chernoff G, et al. Increasing incidence and prevalence of the inflammatory bowel diseases with time, based on systematic review. Gastroenterology. 2012;142(1):46-54.

8. Conigliaro P, Triggianese P, Ballanti E, Perricone C, Perricone R, Chimenti MS. Complement, infection, and autoimmunity. Curr Opin Rheumatol. 2019;31(5):532-41.

9. Lewis MJ, Botto M. Complement deficiencies in humans and animals: links to autoimmunity. Autoimmunity. 2006;39(5):367-78.

10. Brickman CM, Tsokos GC, Balow JE, Lawley TJ, Santaella M, Hammer $\mathrm{CH}$, et al. Immunoregulatory disorders associated with hereditary angioedema. I. Clinical manifestations of autoimmune disease. J Allergy Clin Immunol. 1986;77(5):749-57.

11. Muhlemann MF, Macrae KD, Smith AM, Beck P, Hine I, Hegde U, et al. Hereditary angioedema and thyroid autoimmunity. J Clin Pathol. 1987;40(5):518-23.

12. Agostoni A, Cicardi M. Hereditary and acquired C1-inhibitor deficiency: biological and clinical characteristics in 235 patients. Medicine (Baltimore). 1992;71(4):206-15.

13. Farkas H, Csuka D, Gács J, Czaller I, Zotter Z, Füst G, et al. Lack of increased prevalence of immunoregulatory disorders in hereditary angioedema due to C1-inhibitor deficiency. Clin Immunol. 2011;141(1):58-66.

14. Levy D, Craig T, Keith PK, Krishnarajah G, Beckerman R, Prusty S. Co-occurrence between C1 esterase inhibitor deficiency and autoimmune disease: a systematic literature review. Allergy Asthma Clin Immunol. 2020;16:41.

15. Betschel S, Badiou J, Binkley K, Borici-Mazi R, Hébert J, Kanani A, et al. The International/Canadian hereditary angioedema guideline. Allergy Asthma Clin Immunol. 2019;15:72.

16. Farkas H, Levy D, Supina D, Berger M, Prusty S, Fridman M. Hereditary angioedema C1-esterase inhibitor replacement therapy and coexisting autoimmune disorders: findings from a claims database. Allergy Asthma Clin Immunol. 2020;16:42

\section{Publisher's Note}

Springer Nature remains neutral with regard to jurisdictional claims in published maps and institutional affiliations.

Ready to submit your research? Choose BMC and benefit from:

- fast, convenient online submission

- thorough peer review by experienced researchers in your field

- rapid publication on acceptance

- support for research data, including large and complex data types

- gold Open Access which fosters wider collaboration and increased citations

- maximum visibility for your research: over 100M website views per year

At BMC, research is always in progress.

Learn more biomedcentral.com/submissions 